\title{
Calcium Accumulation, Calcium Distribution, and Biomass Partitioning in Collards
}

\author{
J o n R. J o h n s o n' \\ Clemson University Sandhill Research and Education Center, P. O. Box 23205, Columbia, \\ SC 29224
}

\begin{abstract}
Additional index words. Brassica oleracea Acephala Group, plant nutrition
Abstract. 'Vates' collard (Brassica oleracea L. Acephala Group) was more susceptible to tipburn than 'Blue Max' or 'Heavi Crop' in field and nutrient solution culture experiments. The root system of Vates' was smaller than that of 'Blue Max' in all experiments. Because of its smaller root system, 'Vates' may be more susceptible to moisture stress than 'Blue Max' when grown under high-temperature conditions on sandy soils, thus increasing susceptibility to tipburn. Root system size, however, did not influence Ca accumulation or Ca concentration in the plants. Calcium accumulation rate was higher for 'Blue Max' and 'Heavi Crop' than for Yates' during the 3rd through the 5th weeks of culture, in a nutrient solution that contained $5 \mathrm{mM}$ Ca. Calcium efficiency ratio (CaER, milligrams of dry matter produced per milligram of $\mathrm{Ca}$ in tissue) for young leaves was higher for 'Blue Max' and 'Heavi Crop' than 'for 'Vates' when plants were grown with $1 \mathrm{mM}$ Ca, which may partly explain the greater susceptibility of 'Vates' to tipburn. 'Heavi Crop' had a higher total plant CaER than 'Blue Max' when grown with 5 mM Ca.
\end{abstract}

Tipburn of young leaves of collards was observed during Summer 1988 in growers' fields in central South Carolina. The inward cupping and marginal burn of the young collard leaves appeared to be similar to that associated with tipburn of cabbage, cauliflower, and lettuce. Studies on cabbage (Maynard et al., 1965), cauliflower (Maynard et al., 1981), and lettuce (Collier and Tibbitts, 1984; Thibodeau and Minotti, 1969; Yanagi et al., 1983) indicated that tipburn is caused by a localized $\mathrm{Ca}$ deficiency in the leaf tip. Transport of ${ }^{45} \mathrm{Ca}$ to young leaves was increased and tipburn decreased when transpiration rate was reduced and root pressure flow was increased (Palzkill et al., 1976). Restriction of root growth in Chinese cabbage has been reported to increase the incidence of tipburn (Aloni, 1986).

Variation in CaER (i.e., milligram of dry matter produced per milligram of $\mathrm{Ca}$ in the tissue) among cultivars has been reported for cauliflower (Hochmuth, 1984; Rosen, 1990) and tomato (English and Barker, 1982; English and Maynard, 1981; Giordano et al., 1982). Rosen (1990) reported that the best method to control tipburn of cauliflower was to use resistant cultivars. 'Blue Max', a hybrid collard cultivar, is less susceptible to tipburn than 'Vates', the standard open-pollinated collard cultivar (Johnson, 1991). Soil application of $\mathrm{CaSO}_{4}$ or foliar application of $\mathrm{Ca}\left(\mathrm{NO}_{3}\right)_{2}$ or $\mathrm{CaCl}_{2}$ did not decrease the incidence of tipburn in 'Vates'.

Objectives of these studies were to determine the influence of cultivar on $\mathrm{Ca}$ accumulation rate, $\mathrm{Ca}$ distribution in the plant, and the size of the root system and to determine the relationship between these factors and the incidence of tipburn of collards grown under high temperatures.

Field experiment. 'Vates' and 'Blue Max' collards were grown on a Lakeland sandy soil (Thermic type quartzipsamments) during Summer 1989 at Clemson Experiment Station, Columbia, S.C. Dolomitic lime was applied at $560 \mathrm{~kg}$.ha- 'at 8 weeks before initiating the study to adjust the $\mathrm{pH}$ to 6.0. Preplant broadcast fertilizer was $1 \mathrm{ON}-4.4 \mathrm{P}-8.3 \mathrm{~K}$ applied at $560 \mathrm{~kg} \cdot \mathrm{ha} 1$. Seeds. were planted with a precision seeder on 27 June 1989 at

Received for publication 25 Sept. 1990. Technical Contribution no. 3132 of the South Carolina Agricultural Experiment Station. The cost of publishing this paper was defrayed in part by the payment of page charges. Under postal regulations, this paper therefore must be hereby marked advertisement solely to indicate this fact.

'Assistant Professor.
$15 \mathrm{~cm}$ apart in the row. Plants in the three-leaf stage were thinned to $30 \mathrm{~cm}$ between plants in the row. Plot size was 1.8 x $12.2 \mathrm{~m}$. Each plot included two rows of collards with $71 \mathrm{~cm}$ between individual rows on the bed. The design was a randomized block with four replications. The average air maximum and minimum over the duration of the study was 32 and $21 \mathrm{C}$.

Collards were harvested 58 days after planting the seeds by cutting the plant at the soil surface. Data collected at harvest included a visual tipburn rating, where $1=$ no tipburn and 5 $=$ severe tipburn. Dry weights of foliage and roots were recorded. Roots were removed form a $30-\mathrm{cm}^{2}$ area directly below the harvested plant to a depth of $60 \mathrm{~cm}$. The roots were washed with water to remove soil. Whole-leaf (blade and midrib) tissue samples of young and old leaves were collected for elemental analyses. Young leaves were the terminal five leaves that were 2 to $6 \mathrm{~cm}$ long. All young leaves from the three cultivars were fully exposed to light. 'Vates' has a vertical leaf orientation, whereas 'Blue Max' and 'Heavi Crop' have a more horizontal leaf orientation. The difference in leaf orientation resulted in the young leaves of 'Vates' being somewhat further below the top of the older leaves than for 'Blue Max' and 'Heavi Crop'. Old leaf samples were the eighth leaf from the terminal of the plant. Leaf samples were washed for $1 \mathrm{~min}$ in deionized water before dehydration. The root and foliage samples were dried at $70 \mathrm{C}$ and ground to pass through a 20-mesh screen. Leaf $\mathrm{Ca}$ concentrations were determined by atomic absorption spectroscopy.

Nutrient solution culture experiments. In two greenhouse experiments, 'Vates', 'Blue Max', and 'Heavi Crop' collard plants were grown in 8-liter, 30-cm-diameter plastic containers. These were filled with 7 liters of nutrient solution that was changed every 7 days. Water was added each day to maintain the solution level during the experiments. Air was bubbled into the nutrient solution through glass-bonded air diffusers. The nutrient solution was a modified Hoagland's solution No. 1 (Hoagland and Amen, 1950). All nutrient solutions contained (mg-liter ${ }^{-1}, 234$ $\mathrm{K}, 31 \mathrm{P}, 49 \mathrm{Mg}, 0.5 \mathrm{~B}, 0.5 \mathrm{Mn}, 0.05 \mathrm{Zn}, 0.02 \mathrm{Cu}, 0.01 \mathrm{Mo}$, and $1 \mathrm{Fe}$. Semrestrene 330 [iron chelate) was the source of Fe. Calcium treatments were 1 'and $5 \mathrm{mM}$.. The $1 \mathrm{mrvt} \mathrm{Ca}$ nutrient solution contained $40 \mathrm{mg} \mathrm{Ca} / \mathrm{liter}$ and $184 \mathrm{mg} \mathrm{Na} / \mathrm{liter}$. The 5

$\overline{\text { Abbreviation: }}$ CaER, calcium efficiency ratio. 
$\mathrm{mM}$ Ca nutrient solution contained $200 \mathrm{mg} \mathrm{Ca} /$ liter. The nutrient solution containing $5 \mathrm{mM} \mathrm{Ca}$ is the Ca concentration used in the standard Hoagland nutrient solution (Hoagland and Amen, 1950).

Studies were conducted in a greenhouse with an average daily maximum of $32 \mathrm{C}$ and a minimum of $21 \mathrm{C}$. Seeds were planted in washed, mined sand, and seedlings at the two-leaf stage were transplanted to the plastic containers.

The design for these studies was a split plot with $\mathrm{Ca}$ level as the main plot and cultivar as the subplot. Treatments were replicated four times. A plot consisted of a single plant in a container.

Seeds for Expt. 1 were planted on 28 Dec. 1989. Seedlings were transplanted into plastic containers on 8 Jan. 1990 and harvested 36 days later. Seeds for Expt. 2 were planted on 29 Jan. 1990. Seedlings were transplanted into plastic containers on 15 Feb. 1990 and harvested 35 days later.

,Visual tipburn at the completion of studies was rated on the same scale as that used for the field study. Fresh and dry weights of whole leaves (blade and midrib), petioles, stem, and roots were recorded. Preparation of tissue samples and analysis of tissue samples for $\mathrm{Ca}$ content was the same as that described for the field study. Nutrient solution samples were collected each week from each plot before they were changed and then analyzed for $\mathrm{Ca}$ as for the field study.

Sand culture study. 'Vates', 'Blue Max', and 'Heavi Crop' collard plants were grown in quartz sand in 4-liter $(15 \mathrm{~cm}$ in diameter) pots. The nutrient solution, which contained $5 \mathrm{mrvt}$ $\mathrm{Ca}$, was as described for the nutrient solution culture studies. The solutions. were applied at $600 \mathrm{ml} /$ pot for the first 3 weeks of the study and $1000 \mathrm{ml} /$ pot thereafter through to harvest. Nutrient solutions were applied on days 1, 3, and 5, with an equal amount of deionized water being applied on the other 4 days of the week; some of the water drained from the sand. Collard seeds were planted on 29 Jan. 1990; plants were harvested 49 days later. The design was a randomized block with six replications. A replicate consisted of one plant in a pot. Data collected included dry weights of whole leaves (blade and midrib), petioles, stem, and roots. Sand was removed from roots by washing with water.

Data from field and sand culture studies were processed by analysis of variance, with mean separation by least significant difference. Data from the nutrient solution culture study were analyzed by analysis of variance, with mean separation between cultivars within a $\mathrm{Ca}$ treatment by least significant difference.

Field studies. 'Vates' was more susceptible to tipburn than 'Blue Max' (Table 1); however, for both cultivars, the Ca concentrations "in the young $(0.51 \%$ and $0.44 \%)$ and old (1. $12 \%$ and $0.95 \%$ ) leaves were similar. The shoot and root systems of 'Blue Max' had a higher total dry weight than that of 'Vates', but the shoot : root ratio was higher for 'Vates' than for 'Blue Max'. Roots of 'Vates' were less fibrous than 'Blue Max', based on visual observation.

Table 1. Tipburn severity and biomass partitioning for 'Vates' and 'Blue Max' collards; field experiment, 1989.

\begin{tabular}{|c|c|c|c|c|}
\hline \multirow[b]{2}{*}{ Cultivar } & \multirow{2}{*}{$\begin{array}{l}\text { Tipburn } \\
\text { rating' }\end{array}$} & \multicolumn{2}{|c|}{ Dry wt $(\mathrm{g})$} & \multirow{2}{*}{$\begin{array}{l}\text { Shoot : root } \\
\text { ratio }\end{array}$} \\
\hline & & Shoot & Root & \\
\hline Vates & $4^{*}$ & 38.0 & $3.3^{*}$ & $11.94 *$ \\
\hline Blue Max & 1 & 55.4 & 7.7 & 7.62 \\
\hline
\end{tabular}

'Visual tipburn rating on a scale of $1=$ no tipburn and $5=$ severe tipburn.

"Significant mean separation within columns by LSD at $\boldsymbol{P}=$ O. OS.
Nutrient solution culture. Results of the two studies were similar; therefore, only results of the second study are presented. Leaf area of 'Blue Max' was highest at both Ca levels. Whole-leaf (blade and midrib), petiole, and root dry weights were higher for 'Blue Max' and 'Heavi Crop' than for 'Vates' when grown in $1 \mathrm{mM} \mathrm{Ca}$ nutrient solution (Table 2). The shoot : root ratio was higher for 'Vates' and 'Blue Max' than for 'Heavi Crop' when grown with $1 \mathrm{mM} \mathrm{Ca}$; however, it was similar for the three cultivars when grown with $5 \mathrm{mM}$ Ca. 'Vates' had a lower root dry weight than 'Blue Max' or 'Heavi Crop' when grown with $1 \mathrm{mM} \mathrm{Ca}$, but 'Vates' and 'Blue Max' had a similar and higher root dry weight than 'Heavi Crop' when grown with $5 \mathrm{mM} \mathrm{Ca}$.

'Vates' developed more tipburn than 'Blue Max' or 'Heavi Crop' at both Ca levels (Table 3). Calcium concentration in young leaves was higher for 'Vates' than for 'Blue Max' or 'Heavi Crop' when grown with $1 \mathrm{mM} \mathrm{Ca}$; however, when grown with $5 \mathrm{mM} \mathrm{Ca}$, young leaves of all three contained similar concentrations of $\mathrm{Ca}$ (Table 3). Calcium concentration in mature leaves was similar for the three cultivars at 1 or $5 \mathrm{mM} \mathrm{Ca}$, but about twice as high at 5 as at $1 \mathrm{mM}$ Calcium concentration in petioles was higher for 'Blue Max' than for 'Vates' or 'Heavi Crop' grown with 1 or $5 \mathrm{mM} \mathrm{Ca}$ in the nutrient solution. Petioles apparently accumulated more $\mathrm{Ca}$ in the susceptible than in the resistant cultivar. Stem $\mathrm{Ca}$ concentration was similar for the

Table 2. Biomass partitioning for three cultivars of collards grown with 1 or $5 \mathrm{mM} \mathrm{Ca}$ in nutrient solution culture.

\begin{tabular}{|c|c|c|c|c|c|}
\hline \multirow[b]{2}{*}{ Cultivar } & \multirow{2}{*}{$\begin{array}{l}\text { Leaf } \\
\text { area } \\
\left(\mathrm{cm}^{2}\right)\end{array}$} & \multicolumn{3}{|c|}{ Dry wt (g/plant) } & \multirow{2}{*}{$\begin{array}{c}\text { Shoot : root } \\
\text { ratio }\end{array}$} \\
\hline & & Leaves & Petioles & Roots & \\
\hline \multicolumn{6}{|c|}{$1 \mathrm{mMCa}$} \\
\hline Vates & $4070 \mathrm{c}^{2}$ & $18.4 \mathrm{~b}$ & $5.6 \mathrm{~b}$ & $2.7 \mathrm{~b}$ & $10.3 \mathrm{a}$ \\
\hline Blue Max & 7070 a & $28.3 \mathrm{a}$ & $7.9 \mathrm{a}$ & $4.3 \mathrm{a}$ & $9.8 \mathrm{a}$ \\
\hline Heavi Crop & $5990 \mathrm{~b}$ & 24.7 a & $7.3 \mathrm{a}$ & $4.6 \mathrm{a}$ & $7.7 \mathrm{~b}$ \\
\hline \multicolumn{6}{|c|}{$5 m M C a$} \\
\hline Vates & $4170 \mathrm{~b}$ & $20.6 \mathrm{~b}$ & $5.0 \mathrm{~b}$ & $3.7 \mathrm{a}$ & $8.3 \mathrm{a}$ \\
\hline Blue Max & 6410 a & $26.1 \mathrm{a}$ & $6.5 \mathrm{a}$ & $4.4 \mathrm{a}$ & $8.6 \mathrm{a}$ \\
\hline Heavi Crop & $3380 \mathrm{~b}$ & $15.7 \mathrm{c}$ & $4.8 \mathrm{~b}$ & $2.6 \mathrm{~b}$ & $8.9 \mathrm{a}$ \\
\hline
\end{tabular}

'Mean separation among cultivars within a $\mathrm{Ca}$ treatment by LSD at $\boldsymbol{P}$ $=0.05$.

Table 3. Calcium distribution in three cultivars of collards with 1 or $5 \mathrm{mM} \mathrm{Ca}$ in nutrient solution culture.'

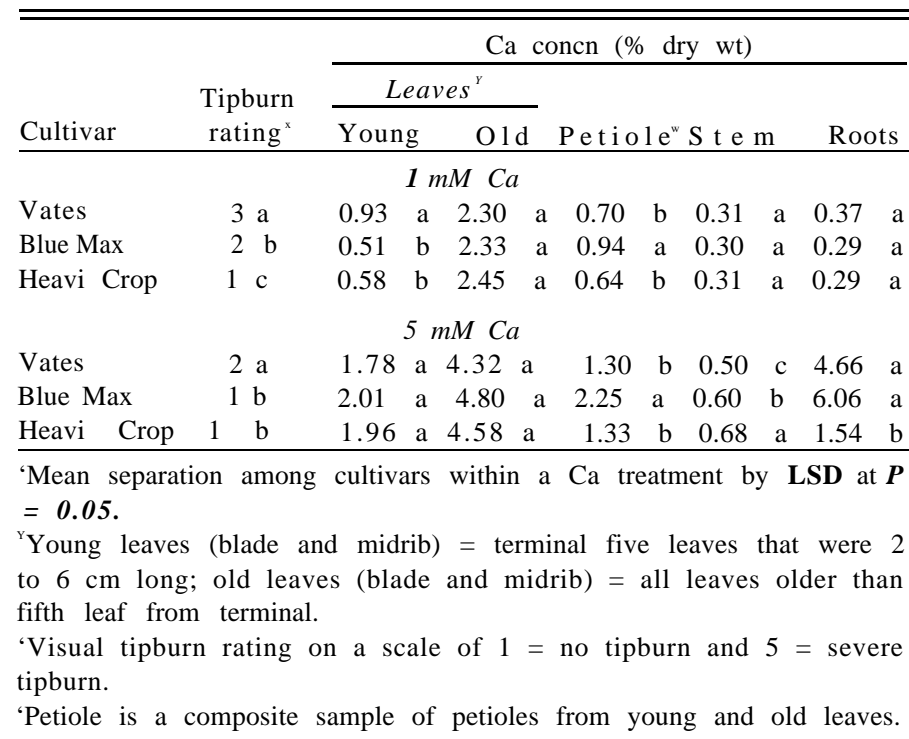


three cultivars grown with $1 \mathrm{mM} \mathrm{Ca}$ in the nutrient solution. Stem Ca concentration was higher for 'Blue Max' and 'Heavi Crop' than for 'Vates'. Root Ca concentration was similar for the three cultivars in $1 \mathrm{mM} \mathrm{Ca}$, but was lower in 'Heavi Crop' than in the other two cultivars when grown with $5 \mathrm{mM} \mathrm{Ca}$.

Calcium accumulation rate (amount of $\mathrm{Ca}$ removed from the nutrient solution per week) was similar for the three cultivars throughout the study for plants with $1 \mathrm{mM} \mathrm{Ca}$ (data not shown). This similarity in $\mathrm{Ca}$ accumulation for the three cultivars indicates that, for plants grown with $1 \mathrm{mM} \mathrm{Ca}$, factors other than total $\mathrm{Ca}$ accumulation determine cultivar susceptibility to tipburn. Other factors that may influence cultivar susceptibility to tipburn may be differences in root growth or moisture relations in the plant. 'Vates' has a more vertical leaf orientation than 'BIue Max' or 'Heati Crop', which results in the young leaves being somewhat further below the top of the outer leaves in 'Vates' than in the others. This may result in less air movement around the young leaves of 'Vates', which may result in reduced transpiration rate and reduced movement of $\mathrm{Ca}$ to the younger leaves. Calcium accumulation during the 2 nd week of the study was similar for the three cultivars supplied with $5 \mathrm{mM} \mathrm{Ca}$ (Table 4). During the $3 \mathrm{rd}$ and 4 th weeks, Ca accumulation was higher for 'Blue Max' than for 'Vates' or 'Heavi Crop'. In the 5th week, the sequence was 'Blue Max' > 'Vates' > 'Heavi Crop'. From the 2 nd to the 5 th week of the study, Ca accumulation rate increased for all cultivars at both $\mathrm{Ca}$ levels $(50$ to $59 \mathrm{mg}$ / plant during week 2, 164 to $233 \mathrm{mg} /$ plant during week 5 for 1 $\mathrm{mM} \mathrm{Ca}$; see Table 4 for $5 \mathrm{mM} \mathrm{Ca}$ ). Tipburn of collards usually does not occur in the field until 3 or 4 weeks before harvest, corresponding to the time when $\mathrm{Ca}$ accumulation is increasing. Tipburn may occur during this time of rapid leaf expansion because the plant is unable to move it rapidly enough to the young leaves for normal growth.

'Blue Max' had a higher CaER in young leaves than 'Vates' at $1 \mathrm{mM} \mathrm{Ca}$, but there was no difference among the cultivars at $5 \mathrm{mM} \mathrm{Ca}$ (Table 5). CaER for old leaves was similar for all cultivars at the 1 or $5 \mathrm{mM} \mathrm{Ca}$ levels, but it was about twice as high at 1 as at $5 \mathrm{mM} \mathrm{Ca}$. CaER for petioles was higher for 'Vates' and 'Heavi Crop' than 'Blue Max' at both levels. The total plant CaER was similar for the three cultivars at the $1 \mathrm{mM}$ Ca level, but 'Blue Max' and 'Vates' had similar total plant $\mathrm{CaER}$ at $5 \mathrm{mM} \mathrm{Ca}$. 'Heavi Crop' had a higher total plant CaER than 'Blue Max' when grown at $5 \mathrm{mM} \mathrm{Ca}$.

Sand culture. Dry weights of whole leaves (blade and midrib) and roots were higher for 'Blue Max' than for 'Vates' or 'Heavi Crop' (Table 6). Petiole dry weight was similar for the three cultivars." Shoot : root ratios were similar for the three cultivars.

Calcium accumulation was higher for 'Blue Max' than 'Vates' when grown with $5 \mathrm{mMl} \mathrm{Ca}$; however, $\mathrm{Ca}$ concentrations in young and old leaves were similar for the two cultivars. CaER in young leaves was higher for 'Blue Max' than 'Vates', indi-

Table 4. Calcium accumulation in leaves of three cultivars of collards grown with $5 \mathrm{mM} \mathrm{Ca}$ in nutrient solution culture.

\begin{tabular}{|c|c|c|c|c|c|}
\hline \multirow[b]{3}{*}{ Cultivar } & \multicolumn{5}{|c|}{ Ca uptake $(\mathrm{mg} / \text { plant })^{2}$} \\
\hline & \multicolumn{2}{|c|}{ Uptake } & (days & \multicolumn{2}{|c|}{ after transplanting) } \\
\hline & $7-14$ & $14-21$ & & $21-28$ & $28-35$ \\
\hline Vates & $68 \mathrm{a}$ & $124 \mathrm{~b}$ & & $422 \mathrm{~b}$ & $604 \mathrm{~b}$ \\
\hline Blue Max & $44 \mathrm{a}$ & $273 a$ & & $569 \mathrm{a}$ & $791 \mathrm{a}$ \\
\hline Heavi Crop & $63 \mathrm{a}$ & $84 \mathrm{~b}$ & & $343 \mathrm{~b}$ & $392 \mathrm{C}$ \\
\hline
\end{tabular}

'Mean separation among cultivars by LSD at $P=0.05$. Calcium uptake during a given week was similar for all cultivars at $1 \mathrm{mM} \mathrm{Ca}$.
Table 5. CaER for three cultivars of collards grown with 1 or $5 \mathrm{mM}$ $\mathrm{Ca}$ in nutrient solution culture.

\begin{tabular}{lcccc}
\hline \hline & \multicolumn{4}{c}{ CaER $^{2}$} \\
\cline { 2 - 5 } Cultivar & \multicolumn{2}{c}{ Leaves $^{\mathrm{Y}}$} & & \\
\cline { 2 - 5 } & Young & Old & Petioles $^{\times}$ & Total plant \\
Vates & $107 \mathrm{~b}$ & $44 \mathrm{a} a$ & $145 \mathrm{a}$ & $69 \mathrm{a}$ \\
Blue Max & $206 \mathrm{a}$ & $43 \mathrm{a}$ & $107 \mathrm{~b}$ & $64 \mathrm{a}$ \\
Heavi Crop & $183 \mathrm{a}$ & $42 \mathrm{a}$ & $158 \mathrm{a}$ & $66 \mathrm{a}$ \\
& & $5 m M \mathrm{Ca}$ & & \\
Vates & $58 \mathrm{a}$ & $24 \mathrm{a}$ & $79 \mathrm{a}$ & $30 \mathrm{ab}$ \\
Blue Max & $50 \mathrm{a}$ & $21 \mathrm{a}$ & $45 \mathrm{~b}$ & $26 \mathrm{~b}$ \\
Heavi Crop & $51 \mathrm{a}$ & $22 \mathrm{a}$ & $75 \mathrm{a}$ & $33 \mathrm{a}$ \\
\hline
\end{tabular}

'Mean separation among cultivars within a Ca level by LSD at $P=$ 0.05 .

${ }^{\mathrm{y}}$ Young leaves (blade and midrib) $=$ terminal five leaves that were 2 to $6 \mathrm{~cm}$ long; old leaves (blade and midrib) =all leaves older than the fifth leaf from the terminal.

${ }^{x}$ Petiole is a composite sample of petioles from young and old leaves.

Table 6. Biomass partitioning for three cultivars of collards grown with $5 \mathrm{mM} \mathrm{Ca}$ in sand culture.

\begin{tabular}{|c|c|c|c|c|c|}
\hline \multirow[b]{2}{*}{ Cultivar } & \multicolumn{4}{|c|}{ Dry wt $(\mathrm{g})^{2}$} & \multirow{2}{*}{$\begin{array}{l}\text { Shoot : root } \\
\text { ratio } \\
\end{array}$} \\
\hline & Leaves & Petioles & Stem & Roots & \\
\hline Vates & $15.4 \mathrm{~b}$ & $4.5 \mathrm{a}$ & $3.0 \mathrm{a}$ & $7.8 \mathrm{~b}$ & $3.0 \mathrm{a}$ \\
\hline Blue Max & $18.1 \mathrm{a}$ & $4.4 \mathrm{a}$ & $3.1 \mathrm{a}$ & $10.3 \mathrm{a}$ & $2.7 \mathrm{a}$ \\
\hline Heavi Crop & $13.9 \mathrm{~b}$ & $3.6 \mathrm{a}$ & $1.6 \mathrm{~b}$ & $7.4 \mathrm{~b}$ & $2.5 \mathrm{a}$ \\
\hline
\end{tabular}

'Mean separation within columns by LSD at $P=0.05$.

eating that young leaves of 'Blue Max' were more efficient in using $\mathrm{Ca}$ than were those of 'Vates'. This difference in CaER in young leaves maybe part of the basis for 'Vates' being more susceptible to tipburn than 'Blue Max'. Total plant CaER was higher for 'Heavi Crop' than 'Blue Max'; however, 'Vates' and 'Blue Max' had similar total plant CaER. Cauliflower cultivars also have been found to differ in CaER (Hochmuth, 1984).

'Vates' had a root system with fewer fibrous roots and lower dry weight than 'Blue Max' in field, nutrient solution culture, and sand culture experiments. Root dry weight did not influence $\mathrm{Ca}$ accumulation or $\mathrm{Ca}$ concentration in the plant. These results are in contrast to those reported for Chinese cabbage, in which restriction of root volume reduced soluble $\mathrm{Ca}$ concentration in leaf sap of tips of young leaves and increased incidence of tipburn (Aloni, 1986).

The best method to control tipburn of collards grown during the summer in the southeastern United States is to use tolerant cultivars.

\section{Literature Cited}

Aloni, B. 1986. Enhancement of leaf tipburn by restricting root growth in Chinese cabbage plants. J. Hort. Sci. 61:509-513.

Collier, G.F. and T.W. Tibbitts. 1984. Effects of relative humidity and root temperature on calcium concentration and tipburn development in lettuce. J. Amer. Soc. Hort. Sci. 109:128-131.

English, J.E. and A.V. Barker. 1982. Water-soluble calcium in Coefficient and Ca-inefficient tomato strains. HortScience 17:929-931.

English, J.E. and D.N. Maynard. 1981. Calcium efficiency among tomato strains. J. Amer. Sot. Hort. Sci. 106:552-557.

Giordano, L. B., W.H. Gabelman, and G.C. Gerloff. 1982. Inheritance of differences in calcium utilization by tomatoes under low-calcium stress. J. Amer. Sot. Hort. Sci. 107:664-669.

Hoagland, D.R. and D.I. Arnon. 1950. The water-culture method for growing plants without soil. California Agr. Expt. Sta. Circ. 347. 
Hochmuth, G.J. 1984. Variation in calcium efficiency among strains of cauliflower. J. Amer. Soc. Hort. Sci. 109:667-672.

Johnson, J.R. 1991. Calcium nutrition and cultivar influence incidence of tipburn of collards. HortScience 26:544-546.

Maynard, D. N., B. Gersten, and H.F. Vemell. 1965. The distribution of calcium as related to internal tipburn, variety and calcium nutrition in cabbage. Proc. Amer. Soc. Hort. Sci; 86:392-396.

Maynard, D. N., D.C. Warner, and J.C. Howell. 1981. Cauliflower leaf tipburn A calcium deficiency disorder. HortScience 16:193-195.

Palzkill, D. A., T. W. Tibbitts, and P.H. Williams. 1976. Enhancement of calcium transport to inner leaves of cabbage for prevention of tipburn. J. Amer. Soc. Hort. Sci. 101:645-648.

Rosen, C.J. 1990. Leaf tipburn in cauliflower as affected by cultivar, calcium spray, and nitrogen nutrition. HortScience 25:660-663.

Thibodeau, P. and P.L. Minotti. 1969. The influence of calcium on the development of lettuce tipburn. J. Amer. Soc. Hort. Sci. 94:372376.

Yanagi, A. A., R.M. Bullock, and J.J. Cho. 1983. Factors involved in the development of tipburn in crisphead lettuce in Hawaii. J. Amer. Soc. Hort. Sci. 108:234-237. 